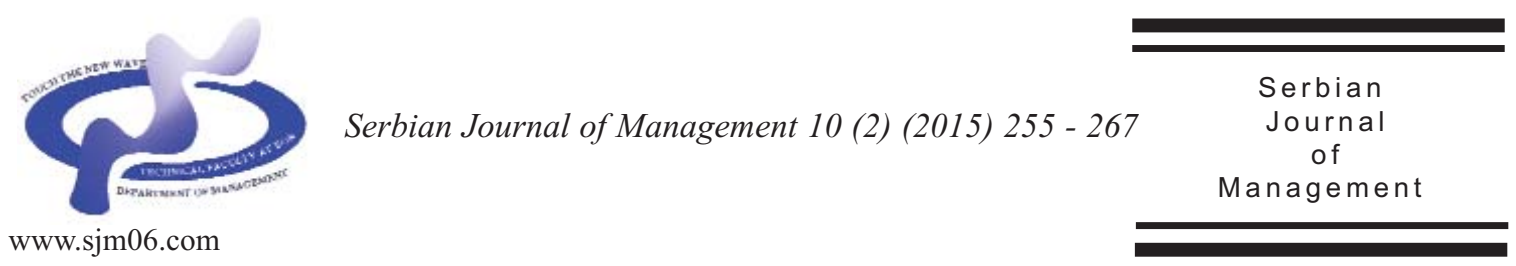

\title{
PLANNING OF INTEGRATED/SUSTAINABLE SOLID WASTE MANAGEMENT (ISWM) - MODEL OF INTEGRATED SOLID WASTE MANAGEMENT IN REPUBLIKA SRPSKA/B\&H
}

\author{
Milan Topić* and Hubert Biedermann \\ Chair of Economic and Business Management, Montanuniversitaet Leoben, \\ Peter Tunner Straße 25-27, 8700 Leoben AustriaAustria
}

(Received 16 December 2014; accepted 27 May 2015)

\begin{abstract}
Municipal solid waste management (MSWM) has become an important issue for countries around the world. The challenges are particularly notable in developing and transitional countries reflected mainly in inappropriate management, underdeveloped technology, an unfavorable economic situation and the lack of environmental awareness, causing a tremendous environmental impact. Today, various models are applied to analyze solid waste management systems from the regional to the municipal levels. Understanding the mechanisms and factors that currently drive the development of waste management is a crucial step for moving forward and planning sustainable waste management systems. The main objective of this paper is to apply the ISWM model, which is based on the Life-Cycle approach and follows the analytical framework methodology, to the research region. The transdisciplinary research framework was empirically tested and subsequently applied in the region Republika Srpska. Using the benchmark methodology, based on environmental, institutional and economical sustainability, the waste management is summarized in assessment profile. The results of the conducted analyses and the application of the developed model can be used further as a basis for the proposal of further strategic, political and managerial changes and support decision makers and stakeholders to handle waste in a cost-efficient and environmentally sound way.
\end{abstract}

Keywords: Integrated/sustainable waste management, planning of SWM

\section{INTRODUCTION}

Increasing population, rapid urbanization and the growth of living standards have significantly accelerated the rate of waste generation in countries around the world. According to the World Bank's global review of solid waste management (SWM), in 2011 alone, urban areas in the world generated about 1.3 billion tonnes of

\footnotetext{
* Corresponding author: milan.topic@unileoben.ac.at

DOI: $10.5937 / \operatorname{sjm} 10-7360$
} 
municipal solid waste and that is expected to increase to approximately 2.2 billion tonnes annually by 2025. Expectations are that waste generation rates in developing countries will more than double over the next two decades (World Bank, 2012). These developing and transitional countries have significant problems in managing solid waste. The reasons are numerous; notably limited resources (financial and social) and enforcement of relevant regulations especially affecting the quality of waste collection and the application of technologies for safe recycling, treatment and disposal (Chen et al., 2010). Therefore, introduction of efficient solid waste management and its affordability will be one of the key challenges of the 21 st century for developing countries, and one of the key responsibilities of local city and municipal governments (UN-Habitat, 2010).

Republika Srpka (RS), an economically developing country, is faced with developing and implementing an effective, functional, adoptable and sustainable waste management system. War and the its aftermath in the 1990s has had a significant impact on the country's economic and environmental situation. The waste management sector in particular, was disadvantaged. The main problems are reflected in inappropriate municipal solid waste management, outdated technology, an unfavorable economic situation and the lack of awareness within the society. In recent years, local authorities have been making significant efforts to improve MSWM. Regulations and policies have been adopted and elaborated; waste management infrastructures are in the process of being developed and improved and commercialization of the sector has been encouraged. However, despite recent investments in the improved operation of regional landfill sites, the lack of suitable facilities, inadequate management structures, the lack of technical skills and poor law enforcement are the main obstacles to the further development of effective and efficient municipal waste management structures.

\section{THEORETICAL FRAMEWORK}

Implementation of effective and sustainable solid waste management in developing and transitional countries is an especially challenging process. A review of the literature suggests that cities and regions worldwide are making improvements, however development is a relatively slow process because of a number of factors (Schżbeler et al., 1996; Tedesse et al., 2008; UN-Habitat, 2010; Wilson et al., 2012; Sim et al., 2013; Topi et al., 2013; Wilson et al., 2013a). One of the major obstacles to improvement is the fact that developing and transitional countries try to simply "copy and paste" developments from developed economies without regard to their actual strengths and needs. However, this practice has shown that there is no one right model that can be applied to all cities and all situations. Therefore, the future development goal should be the encouragement of different ways of thinking and supporting every region to develop an individual solution that is appropriate to its own specific history, economy, demography and culture and in accordance with its unique institutional, environmental and financial resources. Integrated Sustainable Solid Waste Management (ISWM) follows this approach and allows studies of complex and multi-dimensional systems in an integrated 
way and provides a new and modern perspective for further development. Moreover, the ISWM systems combine waste streams, waste collection and treatment and disposal methods, with the objective of achieving environmental benefits, economic optimization and societal acceptability (McDougall et al., 2001). This approach is also a response to a growing global consensus that cities in developing and transitional countries need to take charge of the modernization process and to develop their own models for waste management (UN-Habitat, 2010).

The ISWM model, based on the LifeCycle approach, recognizes three dimensions in analyzing, developing or changing a waste management system: Firstly, the stakeholders - a key element in sustainable development and the role of the legislation in the system; secondly, the technical component of integrated solid waste management system elements such as waste collection and transportation, waste recovery through sorting and recycling options, waste treatment, waste disposal and waste minimization; and thirdly waste management sustainability aspects. Hence, the development of waste management system depends on the successful interaction and integration of a diverse range of activities, processes, technologies and people. The main goal of the model is therefore to support decision-makers, stakeholders and planners to handle the system in an economically and environmentally sound way (Klunert \& Anschutz, 2001). Through the last several years the concept of ISWM and its aspects has been further clarified and is gradually becoming the norm in discussion of solid waste management in developing countries (Abou-Najm \& El-Fadel, 2004; Seadon, 2006; UN-Habitat, 2010; Marschall
\& Farbakhsh, 2013; Wilson et al., 2013a). However, one of the main challenges derived from the analysis has been the usage of various methodologies for data gathering. Moreover, this problem is especially emphasized when the different cities from different countries are compared. In order to solve and minimize those limitations the ISWM benchmarking indicators set was developed (UN-Habitat, 2010; Wilson et al., 2012; Topić, 2014). This set allows benchmarking of a city's performance in waste management, allowing consistent comparison of performance between cities either in developing countries or in the developed world and monitoring changes and progress over time. Topic (2014) research closely this thematic and develops a Model of Integrative/Sustainable Solid Waste Management.

A model (Figure 1) has been built around the analytical framework of UN-HABITAT benchmarking methodology (UN-Habitat, 2010; Wilson et al., 2012; Wilson et al., 2013b), which is based on the concept of integrated and sustainable (solid) waste management, known as ISWM (Klunert \& Anschutz, 2001) and around the phase model of KLAMPFL-PERNOLD (KlampflPernold et al., 2006; Topić et al., 2013). The analytical framework combine relatively standard, quantitative indicators for the three main physical components - collection, treatment/disposal and recycling - with a corresponding, qualitative, composite indicator for the "quality" of service provision for each physical component, as well as five further qualitative, composite indicators which assess performance for the three main aspects of governance, namely inclusivity of stakeholders, financial sustainability and sound institutions \& proactive policies. On the other hand the 
KLAMPFL-PERNOLD phase model allows an indicator-based classification of different countries or regions to determine the stage of waste management development. The classification of the development stage of waste management in a country or a region can be stated by using a few key parameters without large-scale, on-site surveys. The parameters are classified by using an economic, social, legal and ecological perspective. Depending on the waste management phase, certain waste management measures are appropriate and effective.

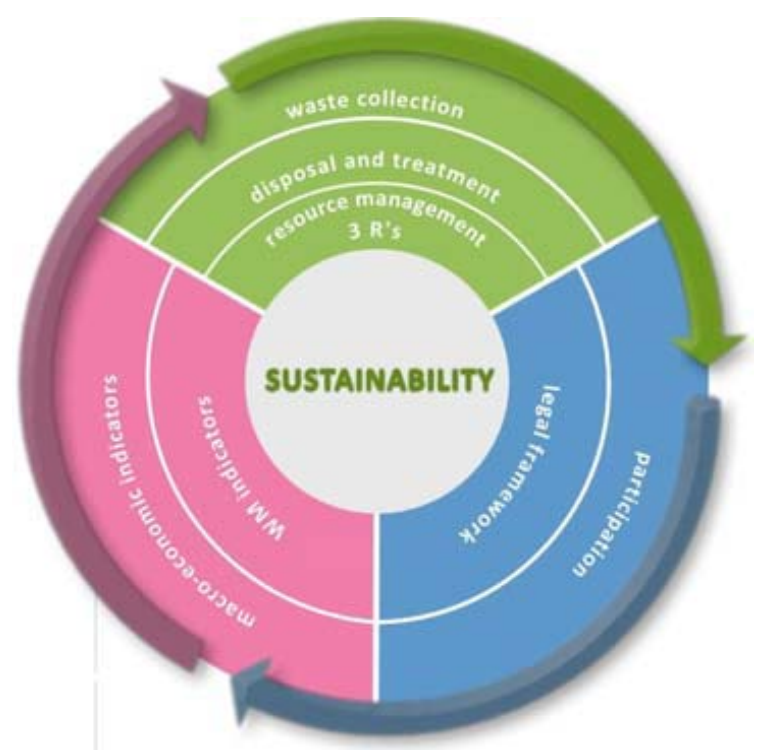

Figure 1. Model of sustainable solid waste management (Topić, 2014)

The ISWM from Topić (2014) model is composed of three dimensions representing the sustainability process. In order to achieve sustainability, all dimensions in the model have to be in motion and connected to each other. The first green component represents the environmental dimension of sustainability and focuses on key drivers for the development of waste management, which include the three key physical components: (1) public health, which depends on a good waste collection service; (2) environmental protection achieved by controlled waste treatment and disposal; and (3) resource management ("3 R's" - reduce, reuse, recycle), which leads to a recycling society and recognizes waste management as a source of raw material. The second, blue element characterizes the institutional and social sustainability aspect. To deliver a well-functioning system and to see contributions and benefits, full participation of all relevant stakeholders (both service users and service providers) have to be ensured. This aspect is considered from two perspectives: firstly, the active participation of the users of solid waste services, which describes how these stakeholders are included in the planning, policy formation and implementation processes. Secondly, the provider participation refers to the performance of the system, and the extent to which it serves all users equitably and according to their needs and preferences. The institutional/social component relies not only on effective stakeholder participation but also on the legal framework. Moreover, it focuses on the implemented legislation and regulation, institutions and legal requirements on the national level and on local institutions and their organizational structures and institutional capacity. The economic aspect is categorized as a special component and presented in red. Sustainability of the solid waste management system relies on the assurance that SWM services and activities are cost-effective and affordable. Moreover, without direct economic benefits, investment and subsidies, the waste management system is not sustainable. To achieve economic sustainability it is necessary to fulfill two different criteria: (1) the macro-economic 
indicators, which represent the overall economic situation of a country, region or a city and (2) specific economic waste management indicators, which give an overview of sustainability in waste management (e.g. cost accounting, system costs recovered from user fees and payments).

\section{RESEARCH METHODOLOGY}

The methodological basis for this paper includes an interdisciplinary approach which is based on the knowledge and experiences accumulated from environmental sciences, natural and technical geosciences and economic sciences. The waste management data was collected through comprehensive on-site research carried out in RS through the research project "Waste Management in the Republic of Srpska". The project application was developed in cooperation with the Department of Geography and Regional Sciences (Austria) and the International Association of Scientists "AIS" in Banja Luka (BIH) and co-financed by the Environment Protection and Energy Efficiency Fund of Republika Srpska. The main aim of the project was to conduct systematic and critical research, using structured data collection, of the municipal solid waste management in RS, in order to detect, identify and solve the problems and challenges which this branch of the economy has to face. In addition, the study analyzed the generation, collection, transportation, recycling and disposal options in municipal solid waste management in RS (Topić et al., 2013). The main part of the data was collected through questionnaires, delivered to municipalities (62) and waste management companies. The collected data was entered into a computer database and analyzed with the statistical program SPSS. In addition to the questionnaire and the literature review, the waste management data was also collected by conducting several structured interviews with decisions makers, communal enterprises and the civil sector. The interviews were addressed to wide range of active stakeholders within the system. For instance, representatives of the Government (Senior Associate for Waste Management at the Ministry of Spatial Planning, Civil Engineering and Ecology); representatives of local governments; service provider managers (technical directors at regional landfill company Ramici in Banja Luka and in Bijeljina; managers of several communal enterprises; managers of several waste management companies); NGO and CBO representatives and scientific researchers from Bosnia and Herzegovina and Serbia (University of Banja Luka; University of Sarajevo; University of Belgrade; University of Novi Sad; Union University).

Furthermore the methodology used in this paper follows the developed ISWM methodology (Topić, 2014), where the indicators and criteria have been identified, supplemented and designed around the three model components. The Model encompasses seven indicators which are selected according to a series of quantitative and qualitative criteria. The quantitative indicators are based on the original methodology (e.g. analytical framework) which is tested on numerous case studies around the world. For each of the criteria comprising a qualitative indicator, there is a device to allow the very different aspects of performance - each ideally being assessed by its own distinct and traceable criterion - to be combined into one indicator; that way, the resulting overall percentages can be 
converted back into a qualitative assessment. The model recognizes the five phases of waste management development. Each phase is color-coded using a "traffic light" system, to assist with a rapid visual assessment of the tabulated data. The color red indicates areas of the system requiring immediate observation and reformation.

The level of the environmental sustainability is analyzed by a set of qualitative and quantitative criteria. For instance, quantities criteria cover the percentage of the service coverage in the tested region, either waste collection coverage, controlled waste disposal and treatment or share of the recycled waste. In addition, for each component tested there is the qualitative criterion. Qualitative criterion is composed of several questions measuring each indicator separately, for instance the quality of waste collection, the degree of environmental protection in waste treatment and disposal and evaluation of resource management.

Further, the sustainability processes in solid waste management cannot be achieved without the effective participation of relevant stakeholders and a legal framework. Therefore, the indicator of participation is analyzed from both sides: user and provider participation. The indicator for user participation is measured by the six qualitative criteria for determining the degree of user participation in the solid waste management system. The questions are related to user involvement in the planning, policy formation, implementation and evaluation of those services, existence of legal rules and regulations which require consultation with and participation of stakeholders outside the institutional structures, existence of user satisfaction measurements, the existence and use of public feedback mechanisms for SWM services, implementation of comprehensive, culturally appropriate public education, behavioral changes and/or awareness raising programs and level of involvement NGOs and CBOs dedicated to conservation and environmental protection. The second indicator is related to provider participation. It again encompasses a set of qualitative criteria measuring the degree to which economic niches in service delivery and recycling are open and accessible to nonstate stakeholders and non-municipal service providers from the formal, private, community or "informal" sectors. The second indicator for measuring the institutional sustainability is built on two criteria: (1) adequacy of national frameworks for solid waste management (measures the existence and implementation of the waste management related legislation at national level) and (2) the degree of local institutional coherence (measures the strength of the local institutional capacities).

The level of economic sustainability is identified by two indicators: firstly, by the macro-economic indicators comprising three quantitative economic criteria: (1) gross domestic product (GDP), (2) unemployment rate and (3) inflation rate; secondly, by specific economic waste management indicators analyzed through a bundle of qualitative questions. The second indicator includes information related to investments, subsidies, cost accounting, affordability of user charges and charging policies.

The final result of the model analysis is the assessment profile consisting of a onepage summary of the benchmark indicators and supplementary background data. In addition to the set of indicators, the assessment profile is supplemented by background information (name of the 
researched region, population and the Human Development Index (HDI) and by key waste related data (waste generation per year ( $\mathrm{t} /$ year), waste generation per capita per year $(\mathrm{kg} /$ year) and municipal solid waste composition with a focus on main components).

\section{RESULTS AND DISCUSSION}

The first step in planning sustainable solid waste management is to conduct comprehensive on-site research and obtain the essential data. Equally important is the understanding of the mechanisms and factors that currently drive the development of solid waste management. This is a crucial step in moving forward and planning sustainable waste management systems. Therefore, the key for effective waste management analysis is a clear understanding of waste management data, such as data about the volumes, mass and nature of each type of waste produced; the collection and transportation system, and treatments and disposal methods.

Municipal solid waste (MSW) presents a significant problem in RS (Topić et al., 2013; Topić, 2014; Topić, 2013; Topić et al., 2013a). Current waste management systems do not follow modern waste management practices due to different historical, financial and social aspects. Fragmentation of solid waste collection and disposal systems; inadequate, technically and legally unapproved landfills; absence of treatment technologies or insufficient number of recycling centers have contributed to the present situation. The material flow diagram, presented in Figure 2, gives an overview of the municipal solid waste management in RS. As the MFD illustrates, the MSWM involves a wide range of stakeholders in the system, including decision-makers, service providers and service users.

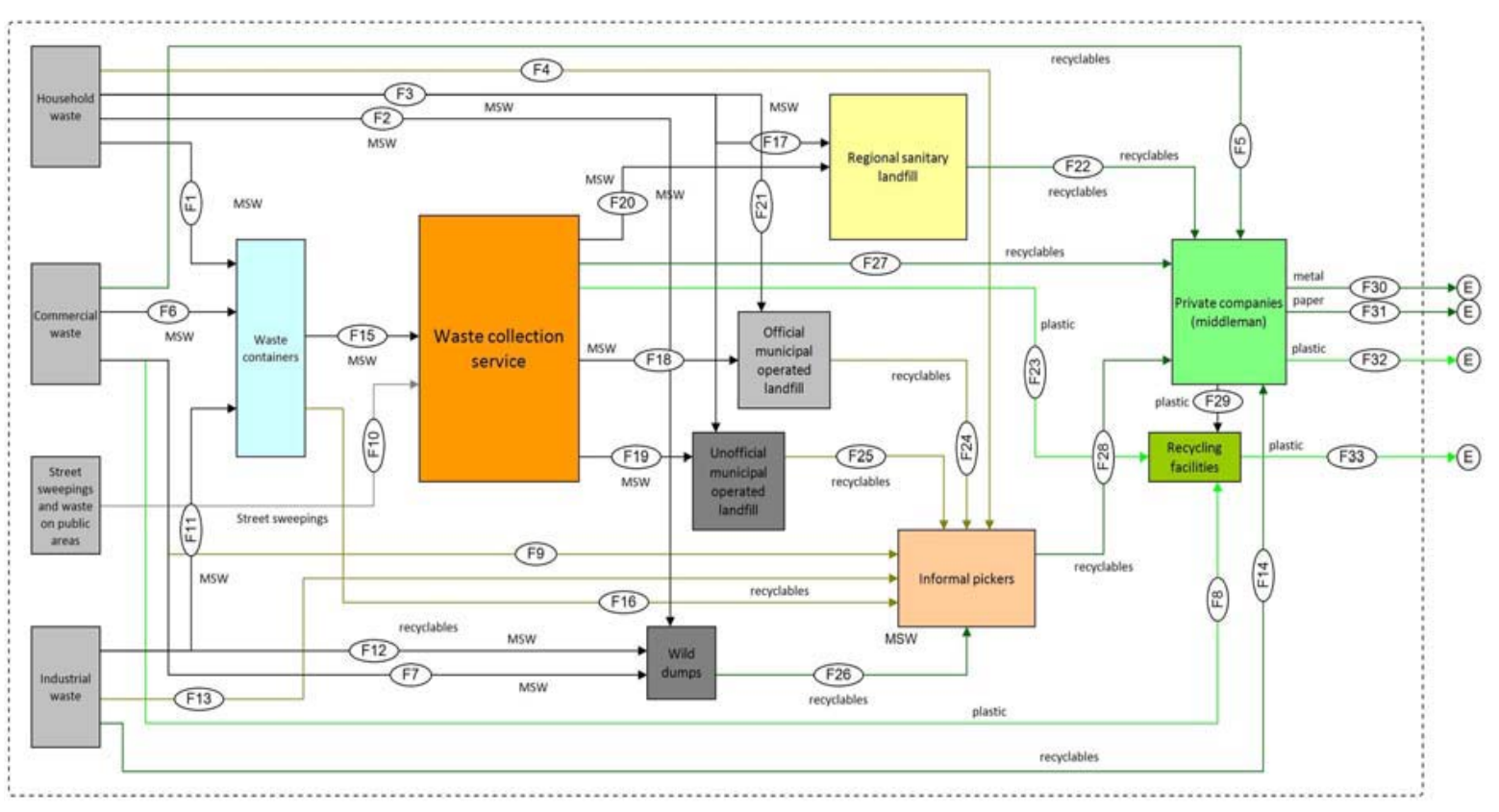

Republika Srpska - MSWM, 2013

Figure 2. Material Flow Diagram for MSWM in Republika Srpska (Topić, 2014) 
The organization of collection, transport and disposal of household waste in RS is under the direct jurisdiction of municipalities. Local municipalities are responsible for organizing effective waste management services within their administrative territories. Regarding the waste collection, local governments are responsible for the collection of municipal solid waste, which is performed by communal enterprises. Three types of companies can be defined through ownership: (1) communal enterprises owned by municipalities, (2) communal enterprises privatized by individuals and (3) private companies which perform waste management. In addition to the diversity in the ownership structure, a variety of services performed by companies has been identified, such as: the distribution of drinking water, sewage and wastewater management, maintenance of municipal hygiene, horticultural production, hazardous waste collection, recycling, maintenance and repair of motor vehicles, funeral related activities, cemetery maintenance, management and maintenance of the green market, chimney services and managing shelters for stray dogs. The total area covered by collection services varies from municipality to municipality. Moreover, the identification of the total collection area depends on the methodology used for analysis. For example, using the official statistics the coverage area of $66 \%$, meaning that of the 376438 tons of waste generated in 2012 only 250223 tons were formally collected. However, according to other sources (e.g. interviews with experts and press releases) or other methodology, the collection coverage is even lower. Comparative analysis of data obtained by questionnaire on the number of households included in a regular system of waste collection out of the total number of households in RS leads to an average coverage rate of $48.18 \%$. Furthermore, significant differences in waste collection coverage between municipalities can be noticed. For instance, the provision of services is lowest in the municipalities Osmaci (9.47\%), Berkovići (18.06\%) and Kalinovik $(24.03 \%)$, while in municipalities Gradiška (77.36\%) Istočno I ovo Sarajevo $(72.42 \%)$ and Banja Luka (89.99\%) coverage is significantly higher. Therefore, it can be concluded that approximately $60 \%$ of RS has organized household collection.

Today the most widely used option for waste "treatment" in RS is waste disposal. The principal methods for waste disposal in RS include (1) waste disposal on sanitary landfill, (2) disposal on regulated local landfills, (3) disposal on unregulated local landfills and (4) disposal on wild dumps. The percentage of the controlled waste treatment and disposal refers to the collected waste that goes to any sort of controlled disposal or treatment facility rather than an uncontrolled site. The coverage of controlled disposal in $\mathrm{RS}$ is $43.61 \%$, emphasizing the fact that controlled waste disposal is conducted only on regional sanitary landfill sites in Banja Luka and Bijeljina, which cover the municipalities within the regions.

Current capacities for recycling options in RS, concerning the range and/or amount of materials processed, are generally very small, particularly if measured as a proportion of total generated waste. A formal or organized system of separate household collection does not exist, and this directly influences the total percentage of recycled waste. Analysis has shown that in some municipalities communal enterprises have launched initiatives for waste recycling (Topić et al., 2013; Topić, 2014). They are 
collecting and manually sorting recyclables such as: paper, plastic (PET packaging and plastic foil) and metal. Yet only few of them have operational recycling yards and most of them are not meeting the criteria of the European Union. Therefore it can be concluded that there is no structured approach to waste recycling in any municipality within the entity. According to interviews with the experts and through comparative analysis of other authors, it can be concluded that the recycling rate of waste in $\mathrm{RS}$ is lower than $10 \%$.

An Integrated Solid Waste Management system cannot be implemented without economic sustainability. The measurement of sustainability in solid waste management in this model is achieved through two indicators: (1) the macro-economic indicators and (2) specific economic waste management indicators. The Gross Domestic Product (GDP) of Republika Srpska accounts for $6006.00 \mathrm{KM}$ per capita (approx. 3 096.00 EUR). This value represents one of the lowest in Europe, due to war destruction in the $1990 \mathrm{~s}$ and slow economic development afterwards. These figures match the first phase of waste management development. Of the total Gross Domestic Product in 2012, the manufacturing sector participated with $7.8 \%$; electricity, gas, steam and air conditioning supply with $4.2 \%$; and mining and quarrying with $2.2 \%$. In terms of employment, these sectors were also dominant, accounting for approximately one-quarter of the total number of employed persons. The average monthly salary in Republika Srpska in 2012 was $818.00 \mathrm{KM}$ (approx. 422.00 EUR). The highest salaries were found in the sectors of financial and insurance activities, in which half of employees have a university degree. They account for $2.8 \%$ of the total number of employed persons and receive on average 1 $280.00 \mathrm{KM}$ per month (Topić et al., 2013a).

\subsection{Assessment profile}

Solid Waste Management in RS is mostly spread between the medium/low and medium phases of development (Figure 3). Significant problems are represented by waste disposal, particularly the unregulated disposal in several municipalities as well as the appearance of a large number of wild dumps in rural areas, and should be rapidly solved in order to reduce harmful effects on humans and the environment. Moreover, the difficult economic situation in the country is a major obstacle to rapid waste management development. The first steps in building a legal framework for environmental protection and waste management have been taken. Adoption of numerous rules and regulations in the country, in accordance with the EU directives, and adoption of procedures for setting up regional sanitary landfills, has facilitated a comprehensive approach to waste management. Despite the non-existent legislation in separate waste collection, there have been some positive improvements in waste recycling, mostly through the initiatives by private waste companies and the informal sector. However, the lack of data collection and incomplete knowledge about waste streams present a constructive challenge for further strategic planning. The existence of waste data is a prerequisite for steering the country towards advanced waste management. Waste recycling will have to become an essential part of waste management in RS, particularly when the country speeds up the process of approximation to the European Union, fulfills the demands made by EU policies and legislation, and notably EU directives, 


\begin{tabular}{|c|c|c|c|c|c|c|c|c|}
\hline \multicolumn{9}{|c|}{ Assessment profile } \\
\hline I. & \multicolumn{8}{|c|}{ Background information } \\
\hline \multirow{3}{*}{\multicolumn{3}{|c|}{$\begin{array}{r}\text { Name of the country/region } \\
\text { Population } \\
\text { Human Development Index }\end{array}$}} & \multicolumn{6}{|c|}{ Bosnia and Herzegovina/ Republika Srpska } \\
\hline & & & \multicolumn{6}{|l|}{$1,326,991$} \\
\hline & & & \multicolumn{6}{|c|}{$0.733 \rightarrow$ Health 0.78 ; living standard 0.62 ; education 0.72} \\
\hline II. & \multicolumn{8}{|c|}{ Key waste-related data } \\
\hline \multirow{3}{*}{\multicolumn{3}{|c|}{$\begin{array}{r}\text { Waste generation } \\
\text { Waste per capita } \\
\text { Waste composition (main components) }\end{array}$}} & \multicolumn{6}{|c|}{376,438 tons $(2012)$} \\
\hline & & & \multicolumn{6}{|c|}{$263 \mathrm{~kg} /$ year } \\
\hline & & & \multicolumn{6}{|l|}{-} \\
\hline \multicolumn{9}{|c|}{ III. $\quad$ Profile } \\
\hline No. & \multirow{2}{*}{$\begin{array}{l}\text { ENVIRONMENTAL } \\
\text { COMPONENT }\end{array}$} & \multirow{2}{*}{\multicolumn{2}{|c|}{ INDICATOR NAME }} & Low & $\begin{array}{c}\text { LOW/ } \\
\text { MEDIUM }\end{array}$ & MEDIUM & $\begin{array}{c}\text { MEDIUM/ } \\
\text { HIGH }\end{array}$ & $\mathrm{HIGH}$ \\
\hline & & & & & & & & \\
\hline \multicolumn{9}{|c|}{ Environmental sustainability } \\
\hline 1. & \multirow{2}{*}{ Waste collection } & \multicolumn{2}{|c|}{$\begin{array}{l}\text { Waste collection } \\
\text { coverage }\end{array}$} & & O & & & \\
\hline 1.Q & & \multicolumn{2}{|c|}{$\begin{array}{l}\text { Quality of waste } \\
\text { collection service }\end{array}$} & & & & & \\
\hline 2. & \multirow{2}{*}{$\begin{array}{l}\text { Waste treatment } \\
\text { and disposal }\end{array}$} & \multicolumn{2}{|c|}{$\begin{array}{l}\text { Controlled treatment or } \\
\text { disposal rate }\end{array}$} & & & & & \\
\hline $2 . Q$ & & \multicolumn{2}{|c|}{$\begin{array}{l}\text { Environmental quality of } \\
\text { waste treatment and } \\
\text { disposal }\end{array}$} & & & & & \\
\hline 3. & \multirow{2}{*}{$\begin{array}{l}\text { "3 R's" - reduce, } \\
\text { reuse and recycle }\end{array}$} & \multicolumn{2}{|c|}{ Recycling rate } & \multicolumn{2}{|c|}{0} & & & \\
\hline $3 . Q$ & & \multicolumn{2}{|c|}{$\begin{array}{l}\text { Quality of " } 3 R^{\prime} s^{\prime} \\
\text { provision }\end{array}$} & & & & & \\
\hline \multicolumn{9}{|c|}{ Institutional/social sustainability } \\
\hline \multirow[b]{2}{*}{4.} & \multirow{2}{*}{ Participation } & \multicolumn{2}{|c|}{ User participation } & & 0 & & & \\
\hline & & \multicolumn{2}{|c|}{ Provider participation } & & & O & & \\
\hline & & National lev & & & & & 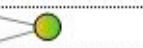 & \\
\hline 5. & Legal tramework & Local level & & & & $\mathrm{O}$ & & \\
\hline Econ & omic sustainability & & & & & & & \\
\hline & & GDP & & & & & & \\
\hline 6. & Macro-economic & Unemploym & nt rate & $y$ & & & & \\
\hline & & Inflation rat & & & & צ & & \\
\hline 7. & WM indicators & $\begin{array}{l}\text { Degree of fi } \\
\text { sustainabilit }\end{array}$ & lancial & & 0 & & & \\
\hline
\end{tabular}

Figure 3. Assessment profile of MSWM in Republika Srpska (Topić, 2014)

that impact directly on waste management options. These include requirements within the Landfill Directive to reduce dependency on landfill for biodegradable waste, and policies that support the waste management hierarchy of options and notably support waste reduction and recovery.

\section{CONCLUSIONS}

The results of the current state analysis have showed that municipal solid waste management (MSWM) presents a significant problem in RS. Current waste management systems in RS do not follow modern waste management practices due to different historical, financial and social aspects. Fragmentation of solid waste collection and disposal systems; inadequate, technically and legally unapproved landfills; absence of treatment technologies or insufficient number of recycling centers have contributed to the present situation. Using the benchmark methodology, based on environmental, institutional and economical sustainability, 
the MSWM in the research region is analyzed and as result the assessment profile is presented. The results of the evaluation show that MSWM in RS is mostly spread between the medium/low and medium phases of development. Severe problems are identified in the waste disposal, particularly unregulated disposal in several municipalities as well as the appearance of a large number of wild dumps in rural areas. These problem areas should be dealt with urgently in order to reduce harmful effects on humans and the environment. One of the main obstacles for the further development lies in the difficult economic situation. However, positive steps toward sustainable development have already been taken. The building of a legal framework for environmental protection and waste management at national level is identified as medium/high. Numerous rules and regulations in the country, in accordance with the EU directives, have been adopted, creating the foundation for future planning. Furthermore, the positive improvements in waste recycling, mostly through the initiatives of private waste companies and the informal sector, show that the service providers have recognized the benefits to be gained from the raw materials market.

Furthermore, the model clearly illustrates the problem of poor legal enforcement. Although the basic environmental and waste management laws are implemented, the poor waste collection coverage and uncontrolled disposal are present in the region. The entity is deficient in capacity to manage complex arrangements with private investors. The private public partnerships (PPP) in the waste management sector are rare causing lack of new investments in new infrastructure and capacity. This is leading to a deficiency in the development of skilled labor, so that there is a critical need for training and transfer of know-how. Another problem area identified by model is the financial viability of communal enterprises which is impaired by inadequate cost accounting and low payment rate of provided service. The combination of these two factors produces a devastating effect on the economic viability of the waste management sector.

\section{References}

Abou-Najm, M., \& El-Fadel, M. (2004). Computer-based interface for an integrated solid waste management optimization model. Environmental Modeling \& Software, 19, 1151-1164.

Chen, X., Geng, Y., \& Fujita, T. (2010). An overview of municipal solid waste management in China. Waste Management, 30, 716-724.

Klampfl-Pernold, H., Gelbmann, U., Abl, C., Pomberger, R., \& Schmidt, G. (2006). Quantum leaps in waste management: Development of an innovation-oriented phase model of European waste management. Shaker Verlag, p.183.

Klampfl-Pernold, H., Schmidt, G., \& Heihl, M.. (2012). If the waste management (still) at the end. Proceedings of the 11 international conference on waste management DepoTech, Leoben, p. 20-34.

Klunert, A., \& Anschutz, J. (2001). Integrated Sustainable Waste Management: the Concept: Tools for Decision-makers, experiences from the Urban Waste Expertise Programme (1995-2001). Waste, Gouda, Netherlands.

Marshall, E.R., \& Farahbakhsh, K. (2013). Systems approaches to integrated solid waste management in developing 


\title{
ПЛАНИРАЊЕ ИНТЕГРИСАНОГ/ОДРЖИВОГ УПРАВЉАЊА ЧВРСТИМ ОТПАДОМ (“ISWМ") - МОДЕЛ УПРАВЉАЊА ЧВРСТИМ ОТПАДОМ У РЕПУБЛИЦИ СРПСКОЈ/ Б И Х
}

\author{
Milan Topić, Hubert Biedermann
}

\section{Извод}

Управљање чврстим комуналним отпадом је постао значајан проблем за земље широм света. Изазови су посебно видљиви у земљама у развоју и транзицији, који се огледају углавном у неодговарајућем начину управљања, неразвијеним технологијама, неповољним економским ситуацијама и недостатцима еколошке свести, што изазива огроман утицај на животну средину. Данас се примењују разни модели за анализу система управљања отпадом од регионалних до општинских нивоа. Разумевање механизама и фактора који тренутно воде развој управљања отпадом представља кључни корак за напредовање и планирање одрживог система управљања отпадом. Главни циљ овога рада је примена „ISWM“ модела на огледном подручију, који се заснива на принципу животног циклуса и прати аналитички оквир методологије. Трансдициплинарна истраживачка методологија је емпириски тестирана и примјењена на региону Републике Српске. Користећи референтну методологију која је базирана на принципима заштите животне средине и институционалне и економске одрживости, сустем управљања отпадом је представљен у профилу процене. Резултати спроведених анализа и примена развијеног модела могу се користити као основа за предлог даљих статешких, политичких и менаџерских промена, као и подршка доносиоцима одлука и заинтересованим странама да управљају отпадом на економичан и еколошко прихватљив начин.

Кључне речи: Интегрисано/одрживо управљање отпадом, планирање управљање чврстим отпадом

countries. Waste Management, 33, 9881003.

Mcdougall, F., White, P., Franke, M., \& Hindke, P. (2001). Integrated solid waste management: a Life Cycle inventory, 2nd Edition, Blackwell Science, Oxford.

Schżbeler, P., Wehrle, K., \& Christen, J. (1996). Conceptual Framework for Municipal Solid Waste Management in LowIncome Countries, UNDP/UNCHS (Habitat)/World Bank/SDC Collaborative Programme on Municipal Solid Waste management in Low-Income Countries; SKAT, St. Gallen, Switzerland.

Seadon, J.K. (2006). Integrated waste management - Looking beyond the solid waste horizon. Waste Management, 26,
1327-1336.

Sim, M.N., Wilson, C.D., Velis, A.C., \& Smith, R.S. (2013). Waste management and recycling in the former Soviet Union: the city of Bishkek, Kyrguz Republic (Kyrgyztan). Waste Management and Research, 31, 106-125.

Tedesse, T., Ruijs, A., \& Hagos, F. (2008). Household waste disposal in Mekelle city, Northern Ethiopia. Waste Management, 28, 2003-2012.

Topić, M. (2013). The road to sustainable waste management in Bosnia and Herzegovina - current developments and challenges. In GEOGRAZ, Austrian Geographical Society, Branch Graz, Austria. Topić, M. (2014). Waste Management in 
Republika Srpska - Strategies and Comparative analysis of solid waste Measurements for Future Waste Collection, management in 20 cities. Waste Treatment, Recycling and Prevention. Management and Research, 30, 237-254.

Doctoral Thesis at University of Graz.

World Bank (2012). What a Waste - A

Topić, M., Preradović, Lj., Stanković, M., Global Review of Solid Waste Management, Zimmermann, F., Fischer, W., Preradović, Urban development series knowledge G., Pešević, D., \& Topić, D. (2013). Waste papers, World Bank, Washington, DC, USA. managment in Republika Srpska: analysis of current situation with special fokus on the comunal enterprises. International Assosiation of scientific workers AIS /Banja Luka/ $\mathrm{BiH}$ and Department of Geography and Regional Science/Graz/ Austria, Banja Luka p. 227.

Topić, M., Zimmermann, F., \& Fischer, W. (2013a). Waste Management Planning: An analysis of the waste management system in Bosnia and Herzegovina. In Planning and normative protection of space and environment: proceedings of the 7 th scientific conference with international participation, Belgrade, p.205-213.

UN-Habitat, (2010). Solid waste management in the world's cities - Water and sanitation in the world's cities 2010, United Nations Human Settlements Programme (UN-HABITAT), Earthscan Ltd, London, UK; Earthscan LLC, Washington, DC, USA.

Wilson, C.D., Costas, A.V., \& Rodic, Lj. (2013a). Integrated sustainable waste management in developing countries. Proceedings of the Institution of Civil Engineers, Waste and Resource Management, 166, 52-68.

Wilson, C.D., Rodic, Lj., Cowing, J.M., Whiteman, A., Stretz, J., \& Scheiberg, A. (2013b). Benchmark Indicators for Integrated \& Sustainable Waste Management (ISWM). ISWA World Congress 2013, Vienna.

Wilson, C.D., Rodic, Lj., Scheinberg, A., Costas, A.V., \& Alabaster, G. (2012). 